Article

\title{
Graphite-Metal Oxide Composites as Potential Anodic Catalysts for Microbial Fuel Cells
}

\author{
Elitsa Chorbadzhiyska ${ }^{1,2}$, Ivo Bardarov ${ }^{1,2}$, Yolina Hubenova ${ }^{3,4}$ and Mario Mitov $1,2, * \mathbb{D}$ \\ 1 Innovative Centre for Eco Energy Technologies, South-West University “Neofit Rilski”, 2700 Blagoevgrad, \\ Bulgaria; elli_e1@swu.bg (E.C.); ivobardarov@swu.bg (I.B.) \\ 2 Department of Chemistry, South-West University “Neofit Rilski”, 2700 Blagoevgrad, Bulgaria \\ 3 Department of Electrocatalysis and Electrocrystallization, Institute of Electrochemistry and Energy Systems \\ “Academician Evgeni Budevski" — Bulgarian Academy of Sciences (IEES-BAS), 1113 Sofia, Bulgaria; \\ y.hubenova@iees.bas.bg \\ 4 Department of Biochemistry and Microbiology, Plovdiv University "Paisii Hilendarski", \\ 4000 Plovdiv, Bulgaria \\ * Correspondence: mitovmario@swu.bg
}

Received: 23 June 2020; Accepted: 15 July 2020; Published: 17 July 2020

check for updates

\begin{abstract}
In this study, graphite-metal oxide ( $\mathrm{Gr}-\mathrm{MO})$ composites were produced and explored as potential anodic catalysts for microbial fuel cells. $\mathrm{Fe}_{2} \mathrm{O}_{3}, \mathrm{Fe}_{3} \mathrm{O}_{4}$, or $\mathrm{Mn}_{3} \mathrm{O}_{4}$ were used as a catalyst precursor. The morphology and structure of the fabricated materials were analyzed by scanning electron microscopy and X-ray diffraction, respectively, and their corrosion resistance was examined by linear voltammetry. The manufactured Gr-MO electrodes were tested at applied constant potential $+0.2 \mathrm{~V}$ (vs. Ag/AgCl) in the presence of pure culture Pseudomonas putida 1046 used as a model biocatalyst. The obtained data showed that the applied poising resulted in a generation of anodic currents, which gradually increased during the long-term experiments, indicating a formation of electroactive biofilms on the electrode surfaces. All composite electrodes exhibited higher electrocatalytic activity compared to the non-modified graphite. The highest current density (ca. $100 \mathrm{~mA} . \mathrm{m}^{-2}$ ), exceeding over eight-fold that with graphite, was achieved with $\mathrm{Gr}-\mathrm{Mn}_{3} \mathrm{O}_{4}$. The additional analyses performed by cyclic voltammetry and electrochemical impedance spectroscopy supported the changes in the electrochemical activity and revealed substantial differences in the mechanism of current generation processes with the use of different catalysts.
\end{abstract}

Keywords: graphite-metal oxide composites; anodic catalysts; Pseudomonas putida; microbial fuel cell

\section{Introduction}

Bioelectrochemical systems (BESs), utilizing whole living microorganisms, are considered as emerging technologies for numerous applications - as power sources for environmental sensors and electronic devices, for wastewater treatment, desalination, bioremediation, electrosynthesis of valuable products, etc. [1]. Despite the huge variety of constructions and purposes, the functioning of all types of BESs developed until now is based on a common principle, namely the unique ability of some prokaryotes and eukaryotes, called exoelectrogens, to couple the catabolic oxidation of available biodegradable substrates with an electrode (anode), used as an external electron acceptor. The use of living microorganisms restricts the BES electrical current and power outputs to values determined by the rate of the extracellularly transferred electrons from the microbial cells to the anode, which in turn is limited by the intensity of the cell metabolism. The current generated by the microbial fuel cells (MFCs), the most popular type of BES, ranges from tenths of $\mathrm{mA} \cdot \mathrm{m}^{-2}$ up to several A. $\mathrm{m}^{-2}$. Different strategies, including optimization of the reactors' design, the electrode materials, 
and other constructive components as well as the cultivation conditions for a certain exoelectrogenic strain, have been applied [2-6] to enhance the extracellular electron transfer (EET) and thus the MFC electrical outputs.

Among all factors affecting the MFC performance, the choice of electrode materials is highly essential since the electrode cost is a key factor for the implementation of the MFC technology at a large scale [7]. Besides high conductivity and corrosion resistance, the anodic materials have to meet additional requirements such as biocompatibility towards the explored bacteria and enhanced active surface area appropriate for biofilm formation. Various materials, mainly carbon-based in different shapes and forms, are applied as anodes in MFCs [3,4]. To reduce the electron transport limitations from the microorganisms to the anode and to improve the MFC performance, different electrode modifications made by electrodeposition of metallic nanostructures $(\mathrm{Ni}, \mathrm{NiFe}, \mathrm{NiFeP})$, pyrolysis of polyacrylonitrile (activated carbon nanofiber), doping with metallic salts, etc., have been accomplished [8-11].

The EET registered by MFC as electric current mimics naturally occurring processes of some microorganisms utilizing metal oxides in the rocks as external electron acceptors to overcome extreme conditions such as substrate and oxygen availability. The use of non-platinum catalysts for electrode modifications is preferred not only for financial reasons but because some dissimilatory metal-reducing microorganisms, such as Geobacter metallireducens and Shewanella oneidensis MR-1 oxidize organic matter and then transfer the released electrons to minerals that contain Fe(III) or Mn(III) or Mn(IV) for respiration [12]. In nature, minerals such as magnetite $\left(\mathrm{Fe}(\mathrm{II}) \mathrm{Fe}(\mathrm{III})_{2} \mathrm{O}_{4}\right)$ and clay minerals that contain $\mathrm{Fe}(\mathrm{II})$ and $\mathrm{Fe}(\mathrm{III})$ act as electron-storage materials that receive electrons from electron-releasing microorganisms $[12,13]$. This is the motivation, namely for bacteria from the genera Geobacter and Shewanella to be the most investigated model microorganisms as biocatalysts in MFC. Recently, it was established that a new bacterial strain, Pseudomonas putida 1046 [14], is capable of expressing a cellular redox compound mediating the electron transfer through a polymer matrix at high positive poising potential, which indicated that the bacteria possess electrogenic properties.

In this study, graphite-based electrodes, modified with $\mathrm{Fe}_{2} \mathrm{O}_{3}, \mathrm{Fe}_{3} \mathrm{O}_{4}$, or $\mathrm{Mn}_{3} \mathrm{O}_{4}$, denoted as $\mathrm{Gr}-\mathrm{Fe}_{2} \mathrm{O}_{3}, \mathrm{Gr}-\mathrm{Fe}_{3} \mathrm{O}_{4}$, and $\mathrm{Gr}-\mathrm{Mn}_{3} \mathrm{O}_{4}$, respectively, were prepared and explored as potential anodic catalysts for MFC using the model bacteria Pseudomonas putida 1046 as a biocatalyst. The developed materials were characterized by scanning electron microscopy (SEM) and X-ray diffraction (XRD). Their corrosion stability in a neutral electrolyte was explored by linear voltammetry (LV). The electrocatalytic properties of the produced materials were tested at the continuously applied constant potential in the biotic environment. The performance of the bioelectrodes was examined by cyclic voltammetry (CV) and electrochemical impedance spectroscopy (EIS). The results obtained with the metal oxide-modified materials and pure graphite were compared and discussed.

\section{Results and Discussion}

\subsection{Composition and Morphology of the Fabricated Materials}

X-ray diffraction was used to establish the chemical composition and the crystal structure of the produced composite materials and to determine if the metal oxides used had undergone alterations by the thermal treatment applied during their preparation. The obtained XRD spectra of the non-modified and modified graphite samples are shown in Figure 1. The characteristic diffraction peaks of graphite, used as a matrix, were registered in all XRD patterns. The most intensive peak, attributed to the carbon (002) crystal plane, appeared at $26.42^{\circ}$, and the rest of the characteristic peaks with smaller intensity, located at $42.36^{\circ}, 44.46^{\circ}$, and $54.51^{\circ}$, corresponded to (100), (101), and (004) crystal planes, respectively (Supplementary Table S1, ICDD PDF No. 00-008-0415). Because of the inclusion of the metal oxides in the graphite matrix, the intensity of these peaks was much lower for all composite materials compared to the non-modified graphite (Supplementary Table S1).

Each of the metal oxides, used as catalyst precursors, have a propensity for reduction at high temperatures. On the other hand, gases with strong reducing properties are released during pyrolysis 
of the carbon pitch, applied as a binder, which supposes that the metal oxides incorporated in the produced composite materials are partially reduced. The results from the XRD analysis supported this suggestion. Besides the four characteristic diffraction peaks corresponding to the $\mathrm{Fe}_{2} \mathrm{O}_{3}$ (110), (202), (116), and (211) crystal planes (ICDD PDF No. 00-033-0664), two peaks, at $35.68^{\circ}$ and $41.78^{\circ}$, attributed to the FeO (222) and (200) crystal planes (ICDD PDF No. 00-074-1886), and two peaks, at $30.11^{\circ}$ and $37.07^{\circ}$, attributed to the $\mathrm{Fe}_{3} \mathrm{O}_{4}$ (220) and (222) crystal planes (ICDD PDF No. 00-076-1849), were also registered in the XRD spectrum of the $\mathrm{Gr}-\mathrm{Fe}_{2} \mathrm{O}_{3}$ (Figure 1a), indicating that the applied preparation method resulted in a partial reduction of the initial $\mathrm{Fe}_{2} \mathrm{O}_{3}$ to $\mathrm{FeO}$. Bearing in mind that $\mathrm{Fe}_{3} \mathrm{O}_{4}$ is a mixed oxide containing both $\mathrm{Fe}_{2} \mathrm{O}_{3}$ and $\mathrm{FeO}$, it is normal to expect that the characteristic peaks of these two oxides should also appear in the XRD pattern of the $\mathrm{Gr}-\mathrm{Fe}_{3} \mathrm{O}_{4}$. However, along with the two characteristic peaks for $\mathrm{FeO}$, only three of the upper described four diffraction peaks of $\mathrm{Fe}_{2} \mathrm{O}_{3}$ (corresponding to (110), (116), and (211) crystal planes) were observed in the obtained XRD spectrum (Figure 1b). Furthermore, the peaks attributed to $\mathrm{Fe}_{2} \mathrm{O}_{3}$ had lower intensity, while the peaks for $\mathrm{FeO}$ were more intense than those in the spectrum of $\mathrm{Gr}-\mathrm{Fe}_{2} \mathrm{O}_{3}$, suggesting that the $\mathrm{Fe}_{2} \mathrm{O}_{3}$ in the initial $\mathrm{Fe}_{3} \mathrm{O}_{4}$ had also undergone a partial reduction during the preparation procedure. In the spectrum of the third composite $\mathrm{Gr}-\mathrm{Mn}_{3} \mathrm{O}_{4}$ material (Figure 1c), except for the peaks of graphite, only three peaks, at $35.02^{\circ}, 40.66^{\circ}$, and $58.85^{\circ}$, attributed to $\mathrm{MnO}$ (200) and (220) crystal planes (ICDD PDF No. 00-075-0626) appeared, which shows that the $\mathrm{Mn}_{2} \mathrm{O}_{3}$ in $\mathrm{Mn}_{3} \mathrm{O}_{4}$ was converted to $\mathrm{MnO}$.

In addition to XRD analyses, the fabricated materials were also examined by scanning electron microscopy, and their surface morphology was compared to that of the non-modified graphite samples (Figure 2). The SEM-images of all modified samples showed inclusions of metal oxides, which changed the morphology of the pure graphite from a typical flake-like structure with graphite micro-sheets to a grooved surface with uneven located metal oxides particles. The samples containing Fe-oxides displayed similar patterns because of their similar composition, as established by XRD. It is supposed that the observed spherical forms of the particles were due to a reduction in surface tension, as described by Jung et al. [15], while the agglomerated formations were associated with particle growth [16]. Although similarities in particle shapes and sizes were observed, the comparison of the SEM images presented in Figure $2 b, c$ revealed a higher loading of metal oxide particles, resulting in more developed surface morphology of the $\mathrm{Gr}-\mathrm{Fe}_{2} \mathrm{O}_{3}$ sample. Given the structural polymorphs of manganese oxides [17], the observed $\mathrm{MnO}$ nanoflakes masked and overlapped the supporting graphite structure and were more difficult to be distinguished on the SEM.

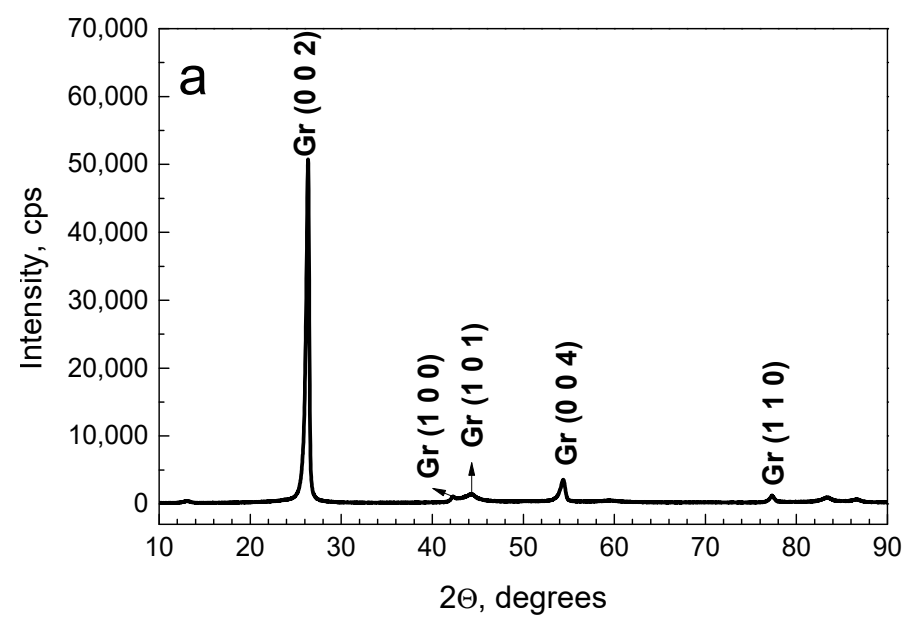

Figure 1. Cont. 

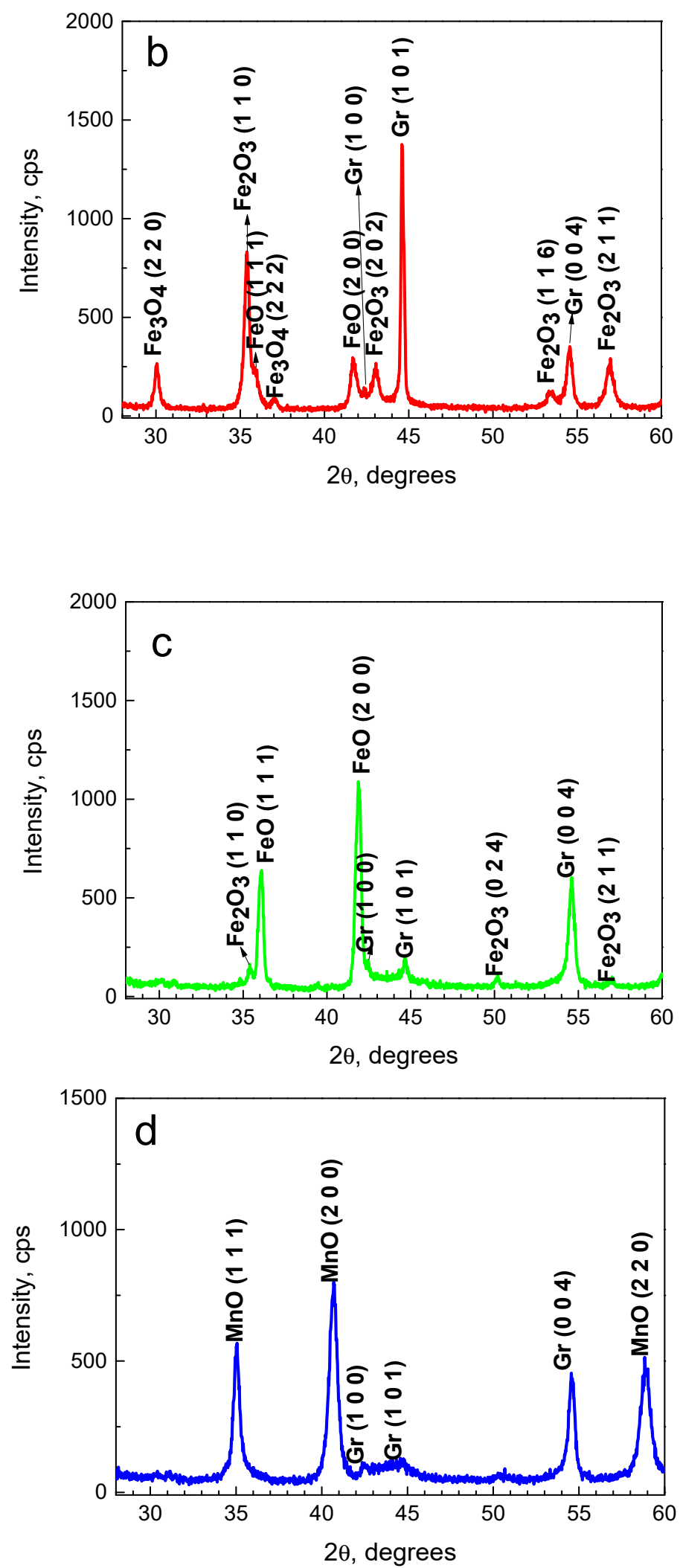

Figure 1. XRD spectra of the produced composite materials: (a) non-modified graphite; (b) $\mathrm{Gr}-\mathrm{Fe}_{2} \mathrm{O}_{3}$; (c) $\mathrm{Gr}-\mathrm{Fe}_{3} \mathrm{O}_{4} ;$ (d) $\mathrm{Gr}-\mathrm{Mn}_{3} \mathrm{O}_{4}$. 


\subsection{Electrochemical Performance of the Composite Materials in Neutral Medium}

The corrosion behavior of the produced materials was investigated by potentiodynamic measurements in neutral phosphate buffer saline (PBS). Because of the compositional and structural inhomogeneity related to the metal oxide inclusion, all modified materials exhibited several fold higher corrosion rates compared to the non-modified graphite (Figure 3). The highest corrosion rate $\left(27.72 \mu \mathrm{A} \cdot \mathrm{cm}^{-2}\right)$ was determined for $\mathrm{Gr}-\mathrm{Mn}_{3} \mathrm{O}_{4}$. Although similarities of both Fe-containing composites were established by $\mathrm{XRD}, \mathrm{Gr}-\mathrm{Fe}_{3} \mathrm{O}_{4}$ possessed corrosion resistance with an order of magnitude higher $\left(2.35 \mu \mathrm{A} . \mathrm{cm}^{-2}\right)$ than that of $\mathrm{Gr}-\mathrm{Fe}_{2} \mathrm{O}_{3}\left(26.37 \mu \mathrm{A} . \mathrm{cm}^{-2}\right)$, which could be attributed to the more developed surface of the latter providing more available active sites. Despite the lower corrosion resistance of the modified electrodes, the estimated corrosion rates were comparable to those obtained with other materials such as austenitic stainless steel [18] and electrodeposited $\mathrm{MnO}_{2}$ [19] explored in neutral PBS, which gave us reason to investigate the newly produced composites as potential anodic catalysts for MFC application.
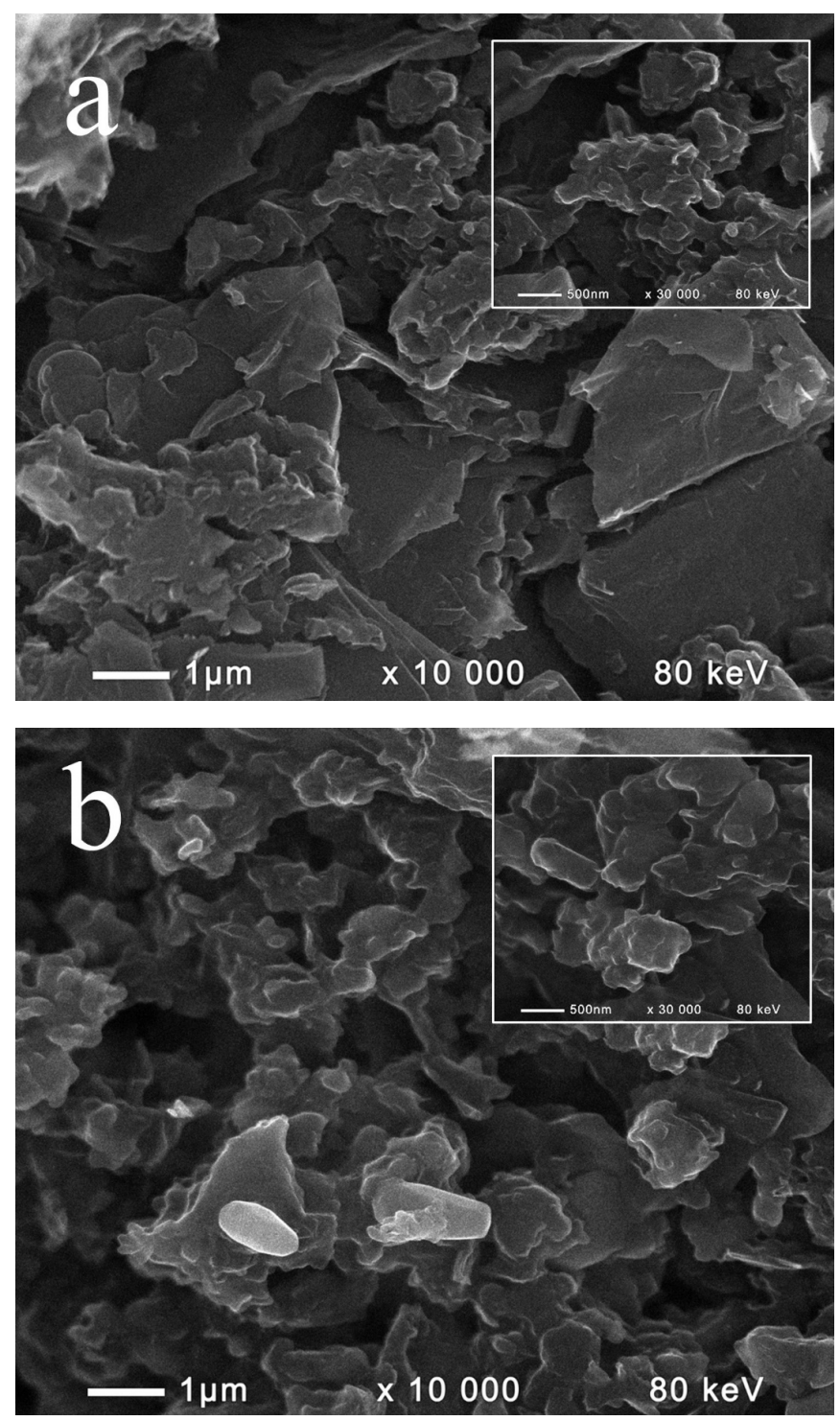

Figure 2. Cont. 

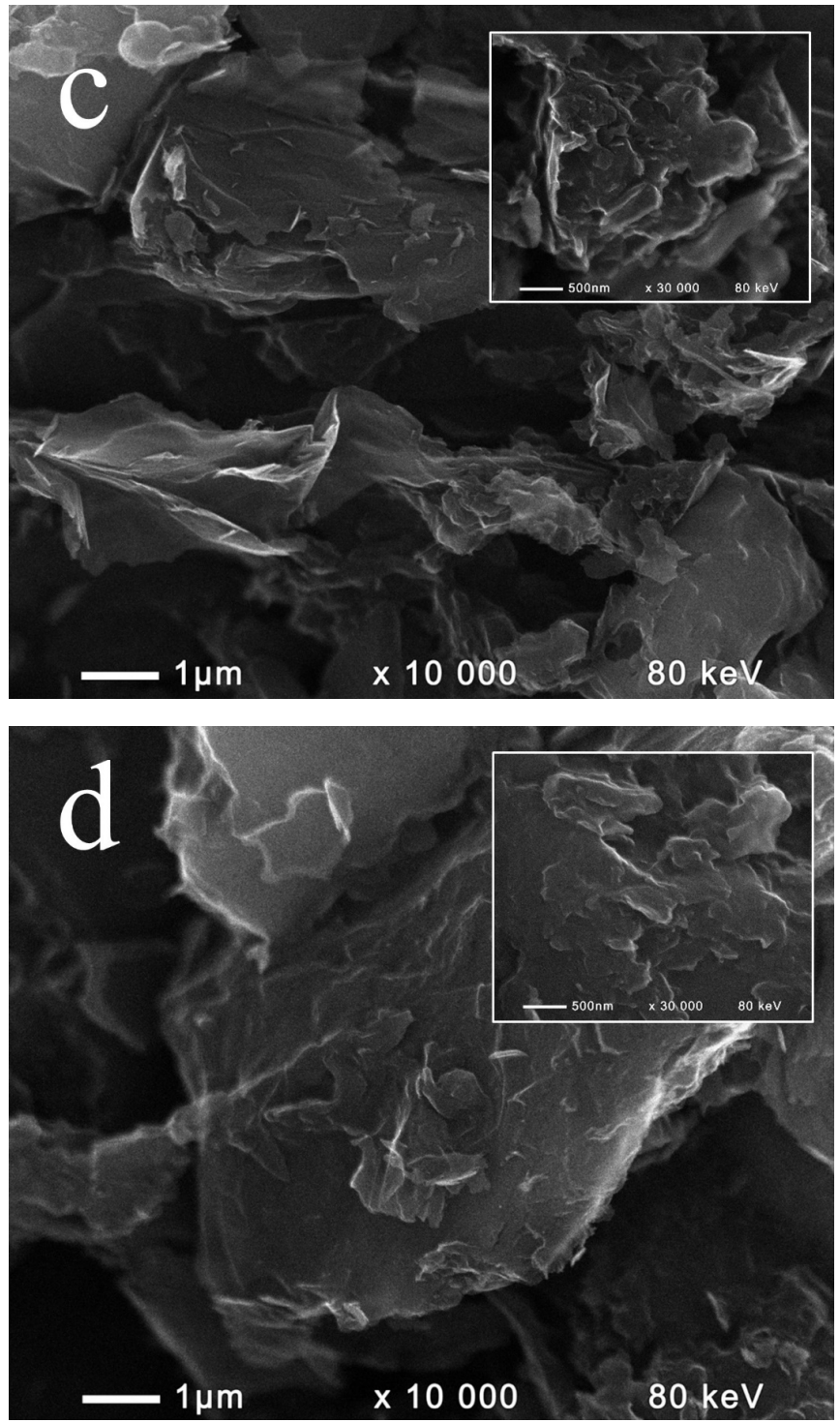

Figure 2. SEM images of the fabricated materials at magnification of $10,000 \times$, inset $30,000 \times$ : (a) non-modified graphite; (b) $\mathrm{Gr}-\mathrm{Fe}_{2} \mathrm{O}_{3} ;$ (c) $\mathrm{Gr}-\mathrm{Fe}_{3} \mathrm{O}_{4} ;$ (d) $\mathrm{Gr}-\mathrm{Mn}_{3} \mathrm{O}_{4}$.

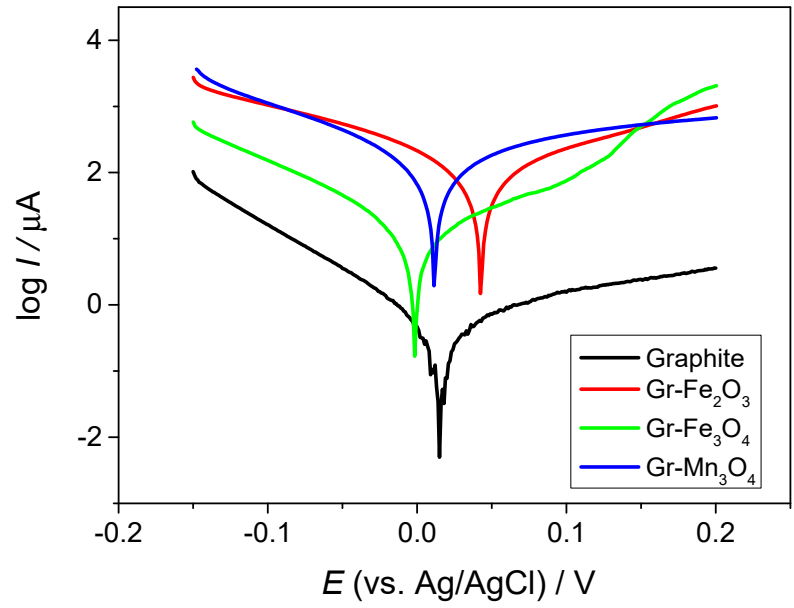

Figure 3. Tafel plots of the modified and non-modified graphite electrodes in $0.1 \mathrm{M}$ PBS (pH 7). 
Before inoculation with bacteria, the electrochemical behavior of the studied electrodes in the used cultivation medium was examined by CV. A lack of expressed peaks as well as an increase in capacitive currents were observed for all modified electrodes compared to the unmodified graphite under abiotic conditions (Supplementary Figure S1), indicating an increase in the electrochemically active surface [20] as a result of the performed modification. The increase of capacitive currents of the modified electrodes was most significant for $\mathrm{Gr}-\mathrm{Mn}_{3} \mathrm{O}_{4}$, followed by $\mathrm{Gr}-\mathrm{Fe}_{3} \mathrm{O}_{4}$ and $\mathrm{Gr}-\mathrm{Fe}_{2} \mathrm{O}_{3}$.

\subsection{Electrochemical Analyses of Modified Electrodes in the Presence of Bacteria}

The electrochemical behavior of the modified electrodes was also investigated in the presence of the bacterium Pseudomonas putida 1046 as a biocatalyst in a three-electrode cell.

At the beginning of this experimental set-up, the open circuit potentials $(\mathrm{OCP})$ of the functionalized electrodes were measured in a non-inoculated nutrient medium. For all composite electrodes, the OCPs were shifted in a positive direction compared to that of the non-modified graphite electrodes (Supplementary Table S2), which was assigned to the inclusion of the metal oxides in the graphite matrix. After inoculation with P. putida 1046, the OCP values considerably changed, shifting in a negative direction for both electrodes, modified with iron oxides, and in a positive direction for the $\mathrm{Gr}-\mathrm{Mn}_{3} \mathrm{O}_{4}$ sample. These changes suggest a rearrangement of the double electric layer in the vicinity of the electrode surfaces, affected by the presence of bacteria. The obtained OCPs reflected the initial current response in the successive chronoamperometric measurements when all studied electrodes were continuously poised at $+0.2 \mathrm{~V}$ (vs. $\mathrm{Ag} / \mathrm{AgCl}$ ) (Figure 4). Because of the more positive OCP of $\mathrm{Gr}-\mathrm{Mn}_{3} \mathrm{O}_{4}$ compared to the applied potential, the current in this system started from negative values, while for the other electrodes possessing more negative OCP values, the initial current was positive.

During the long-term poising, the current increased for all investigated electrodes except for $\mathrm{Gr}-\mathrm{Fe}_{3} \mathrm{O}_{4}$. Although the current started from the highest value, namely with this electrode, it steeply decreased and after two days of poising reached steady-state levels close to those of the non-modified graphite electrode. On the contrary, starting from negative values, the highest current density of $100 \mathrm{~mA} \cdot \mathrm{m}^{-2}$ was achieved with the manganese-containing electrode, while the values of the generated currents obtained with $\mathrm{Gr}-\mathrm{Fe}_{2} \mathrm{O}_{3}$ were twice as higher as those of $\mathrm{Gr}-\mathrm{Fe}_{3} \mathrm{O}_{4}$. Furthermore, the influence of the light illumination on the electrical performance was observed. The current began to increase right after sunrise, and the maximal values were achieved near the daily peaks of light intensity. After that, the current decreased slightly until the end of the photoperiods and during the whole dark periods. The highest amplitude of the current oscillations was recorded for $\mathrm{Gr}-\mathrm{Mn}_{3} \mathrm{O}_{4}$ electrodes. These observations suggest that some photosensitive bacterial molecules contributed to the current generation processes.

The performance of the bioelectrodes was further investigated by CV and EIS. The differences in the cyclic voltammograms obtained with the different electrode types supposed that the electrode modifications influenced the redox behavior of P. putida (Figure 5a) and probably its biofilm formation strategies. At the fifth day after inoculation, the time corresponding to biofilm formation stage [21], a well-defined anodic peak at $-0.03 \mathrm{~V}$ (vs. $\mathrm{Ag} / \mathrm{AgCl}$ ) appeared in the $\mathrm{CV}$ of the non-modified graphite (Figure 5a-inset), indicating putative participation of cytochrome $c$ type molecules [22] in the extracellular electron transfer from the bacteria to the electrode. This peak was disguised in the CVs obtained with the composite electrodes; however, up to a five-fold increase in the anodic currents compared to those at the abiotic conditions (Supplementary Figure S1) was registered, suggesting that a direct electron transfer between bacterial biofilms and modified electrodes could occur [23]. It is supposed that the presence of Fe- and Mn-oxides on the electrode surface provoked bacterial cells to use them for the implementation of the respiration processes [24]. 


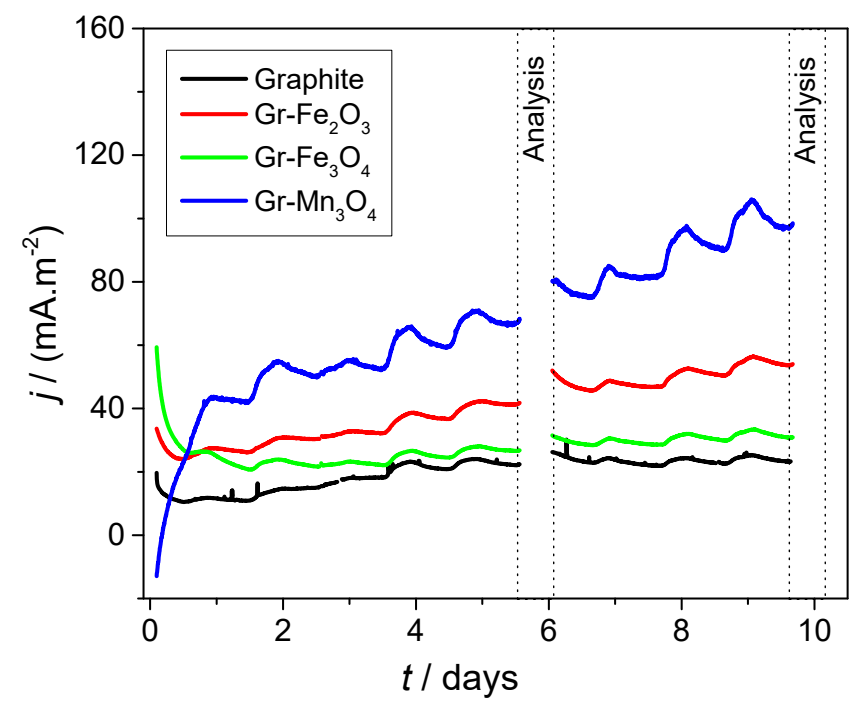

Figure 4. Current density obtained with $\mathrm{Gr}-\mathrm{Fe}_{2} \mathrm{O}_{3}, \mathrm{Gr}-\mathrm{Fe}_{3} \mathrm{O}_{4}, \mathrm{Gr}-\mathrm{Mn}_{3} \mathrm{O}_{4}$, and bare graphite at continuously applied potential of $+0.2 \mathrm{~V}$ (vs. $\mathrm{Ag} / \mathrm{AgCl}$ ) in the presence of P. putida 1046.
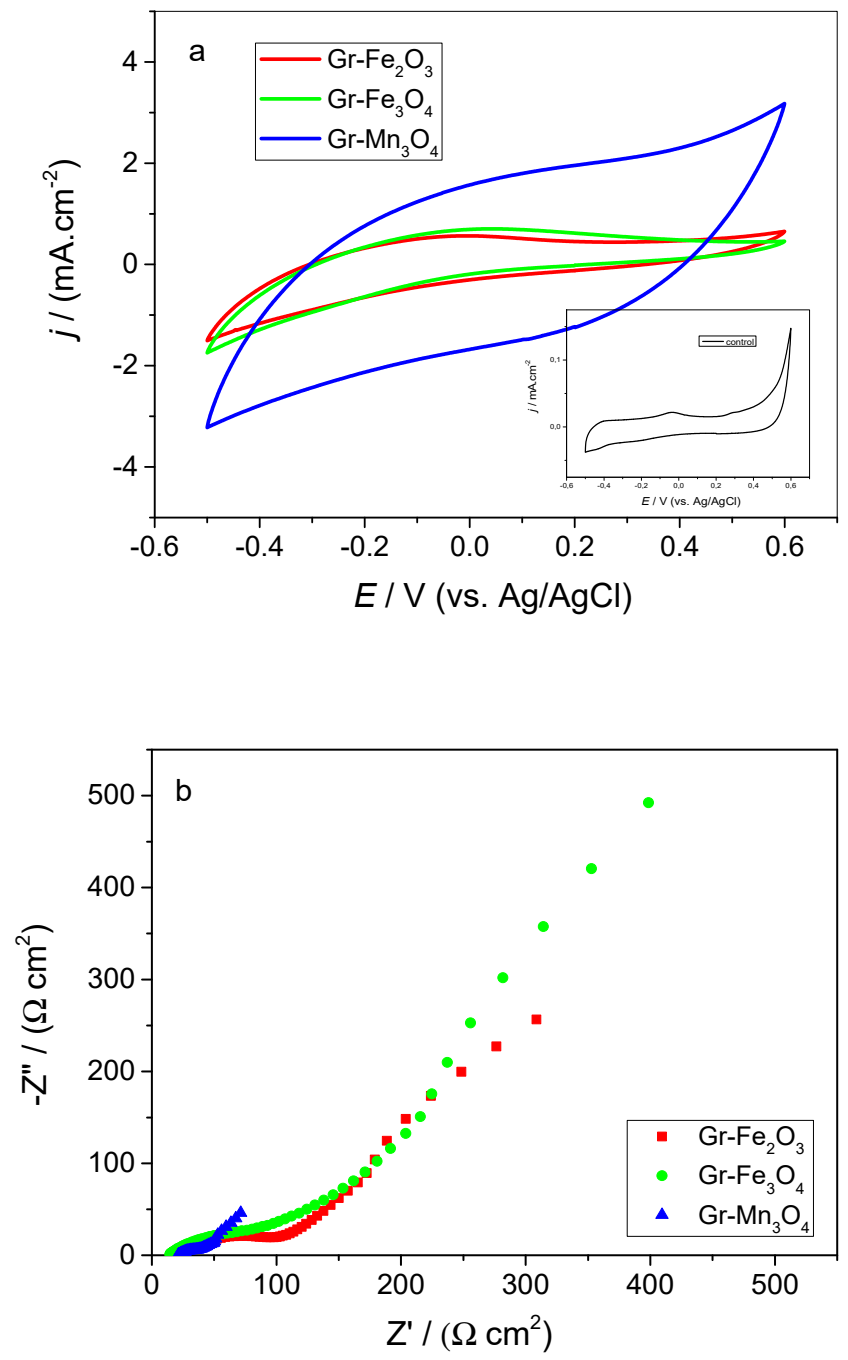

Figure 5. Cont. 


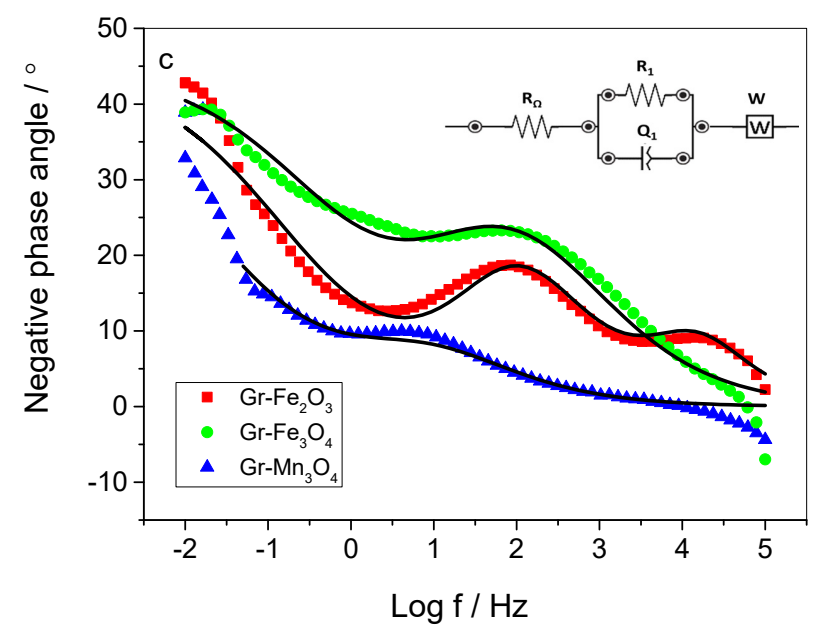

Figure 5. Electrochemical behavior of the fabricated materials in the presence of Pseudomonas putida 1046: (a) cyclic voltammograms obtained on the 5th day, inset-non-modified graphite; (b) Nyquist and (c) Bode plots of the EIS, respectively, carried out on the $10^{\text {th }}$ day of cultivation, $\mathrm{E}_{\mathrm{dc}}=+100 \mathrm{mV}$; measured data-scatters, fitted data-lines.

The impedance spectra of the investigated materials in the presence of bacteria are presented as Nyquist and Bode plots in Figure $5 b, c$, and the impedance parameters, derived from the fitted spectra, are summarized in Table 1. The experimental EIS data fit well to the equivalent circuit models shown in Table 1 and the inset of Figure 5c. The magnification in the high-frequency region of the Nyquist plot reveals a depressed semi arc for all samples, which requires the use of constant phase elements (CPE), defined as $1 / Z=Q(j \omega)^{n}$, where $Q$ is a numerical value of the admittance $(1 /|Z|)$ at radial frequency $\omega=1$, and $\mathrm{n}$ is an empirical nonideality constant, to reproduce the behavior of non-ideal capacitors. The models for $\mathrm{Gr}-\mathrm{Fe}_{3} \mathrm{O}_{4}$ and $\mathrm{Gr}-\mathrm{Mn}_{3} \mathrm{O}_{4}$ are identical, including a resistor $\left(\mathrm{R}_{\Omega}\right)$, accounting for the solution resistance, connected in series with a charge transfer resistor $\left(\mathrm{R}_{1}\right)$ and $C P E\left(\mathrm{Q}_{1}, \mathrm{n}_{1}\right)$ circuit, followed by Warburg diffusion element, while the model determined for $\mathrm{Gr}-\mathrm{Fe}_{2} \mathrm{O}_{3}$ shows a two-time constant reaction, presented as a second, connected in series $\left(\mathrm{R}_{2} \mathrm{Q}_{2}\right)$-couple before the Warburg element. The main difference in the composition of $\mathrm{Gr}-\mathrm{Fe}_{2} \mathrm{O}_{3}$ and $\mathrm{Gr}-\mathrm{Fe}_{3} \mathrm{O}_{4}$, established by $\mathrm{XRD}$, was related to the peaks attributed to $\mathrm{Fe}_{3} \mathrm{O}_{4}$. As reported by Wang et al. [25], $\mathrm{Fe}_{3} \mathrm{O}_{4}$ can form small iron oxide clusters, in which the Fe-electron affinity increases with the number of $\mathrm{O}$ atoms, consistent with an increasing degree of oxidation. As far as the first time constant of $\mathrm{Gr}-\mathrm{Fe}_{2} \mathrm{O}_{3}$ is observed at the high-frequency range, it is suggested that these clusters contribute to the charge transfer reactions. The higher loading of iron oxides $\left(\mathrm{FeO}_{,} \mathrm{Fe}_{2} \mathrm{O}_{3}, \mathrm{Fe}_{3} \mathrm{O}_{4}\right)$ on the graphite surface creates a bigger number of clusters and agglomerates, which forms a second interface between the graphite support and the biological component. Low ohmic resistance $\left(\mathrm{R}_{\Omega}\right)$ was determined for all samples, which indicates that the bacteria formed biofilms on the electrode surfaces, and the biofilm growth did not influence the ionic conductivity of the system. The analysis of the fitted data revealed that $\mathrm{Gr}-\mathrm{Mn}_{3} \mathrm{O}_{4}$ exhibited three-times smaller charge transfer resistance $\left(R_{1}\right)$ and with an order of magnitude lower Warburg element $(W)$ compared to the other composite samples, which explains the highest current values achieved with this electrode in the presence of P. putida. At the same time, for $\mathrm{Gr}-\mathrm{Mn}_{3} \mathrm{O}_{4}$ the value of $\mathrm{Q}_{1}$, reflecting the electrical double layer capacitance, was about 30-fold and 8-fold larger than those of $\mathrm{Gr}-\mathrm{Fe}_{2} \mathrm{O}_{3}$ and $\mathrm{Gr}-\mathrm{Fe}_{3} \mathrm{O}_{4}$, respectively, which confirms that $\mathrm{Gr}-\mathrm{Mn}_{3} \mathrm{O}_{4}$ possessed the most developed active surface, facilitating to a greater extent the biofilm formation and EET processes. The better performance of $\mathrm{Gr}-\mathrm{Fe}_{2} \mathrm{O}_{3}$ than that of $\mathrm{Gr}-\mathrm{Fe}_{3} \mathrm{O}_{4}$ could be assigned to the twice smaller Warburg diffusion element, resulting in lower diffusion hindrances in the low-frequency range (Figure $5 b$ ). The diffusion limitations decreased in the following order: graphite, $\mathrm{Gr}-\mathrm{Fe}_{3} \mathrm{O}_{4}, \mathrm{Gr}-\mathrm{Fe} \mathrm{O}_{3}, \mathrm{Gr}-\mathrm{Mn}_{3} \mathrm{O}_{4}$. This corresponds to an increase in the reverse order electrochemically-active surface established by $\mathrm{CV}$. 
Table 1. Parameters of the equivalent circuit models obtained by fitting of impedance spectra presented in Figure 5b,c.

\begin{tabular}{lccc}
\hline Circuit Element/Unit & $\mathbf{G r}-\mathrm{Fe}_{\mathbf{2}} \mathbf{O}_{\mathbf{3}}$ & $\mathbf{G r}-\mathbf{F e}_{\mathbf{3}} \mathbf{O}_{\mathbf{4}}$ & $\mathbf{G r}-\mathbf{M n}_{\mathbf{3}} \mathbf{O}_{\mathbf{4}}$ \\
\hline Equivalent Circuit Model & $\mathbf{R}_{\Omega}\left(\mathbf{R}_{\mathbf{1}} \mathbf{Q}_{\mathbf{1}}\right)\left(\mathbf{R}_{\mathbf{2}} \mathbf{Q}_{\mathbf{2}}\right) \mathbf{W}$ & $\mathbf{R}_{\boldsymbol{\Omega}}\left(\mathbf{R}_{\mathbf{1}} \mathbf{Q}_{\mathbf{1}}\right) \mathbf{W}$ & $\mathbf{R}_{\boldsymbol{\Omega}}\left(\mathbf{R}_{\mathbf{1}} \mathbf{Q}_{\mathbf{1}}\right) \mathbf{W}$ \\
\hline $\mathrm{R}_{\Omega}, \Omega$ & 5.04 & 3.63 & 5.40 \\
$\mathrm{R}_{1}, \Omega$ & 11.93 & 13.96 & 3.50 \\
$\mathrm{Q}_{1}, \mu \mathrm{T}$ & 1450 & 5500 & 41,500 \\
$\mathrm{n}_{1}, \phi$ & 0.701 & 0.544 & 0.553 \\
$\mathrm{R}_{2}, \Omega$ & 2.18 & - & - \\
$\mathrm{Q}_{2}, \mu \mathrm{T}$ & 40.16 & - & - \\
$\mathrm{n}_{2}, \phi$ & 0.832 & - & - \\
$\mathrm{W}, \mathrm{K} \sigma$ & 0.014 & 0.025 & 0.002 \\
\hline
\end{tabular}

The results obtained in the presence of P. putida 1046 confirmed that this bacterial strain was capable of transferring extracellularly electrons to the modified and non-modified graphite electrodes and are in good agreement with the recently established electroactivity of this strain [26]. The different current generated revealed that bacterial components, contributing to the electrochemical activity and the electrical outputs, used the metal oxides on the electrode surface in a specific way. In addition to the more developed active surfaces identified by CV and EIS, the better performance of the modified graphite electrodes could be attributed to the presence of Fe and Mn, which can be reversibly converted into different oxidation states. It may be supposed that in the initial stage of the chronoamperometric experiments the applied positive potential of $+0.2 \mathrm{~V}$ (vs. $\mathrm{Ag} / \mathrm{AgCl}$ ) attracted electrostatically the negatively charged bacterial cells to the electrode surface, initiating a biofilm formation [27]. It has been reported that P. putida spp. are Mn-oxidizing bacteria that oxidize Mn(II) to Mn(IV) oxides as a strategy for oxidative stress protection [28,29], which suggests that the bacterial cells attached on the Gr- $\mathrm{Mn}_{3} \mathrm{O}_{4}$ electrode may convert the available $\mathrm{MnO}$ into $\mathrm{MnO}_{2}$ as a protective extracellular shield and terminal electron acceptor. Such an assumption is supported by the rapid change of the initial negative to positive current (Figure 4), which within one day reached values exceeding those generated by the systems utilizing the other electrodes. It can be assumed that the initial higher anodic currents recorded with the two iron-containing composite electrodes were related to electrochemical oxidation of the available FeO as a result of the applied positive potential. The observed light-dependent current fluctuations in the subsequent stages of the chronoamperometric experiment could be related either to the photosensitivity of the electrode composite ingredients or to the presence of the biological component in the system interacting with the metal ions from the electrodes. Several papers provide evidence about photoactivity of nanostructured iron and manganese oxides produced by different methods for a variety of photocatalytic applications [17,30-35]. Novel nano-carbon based materials such as graphene and graphene quantum dots also demonstrate a size-tunable photoresponse, providing a new way for the creation of low cost, high performance carbon-based devices [36]. Given that the composite materials used in this study consist of agglomerates larger than $100 \mathrm{~nm}$ (Figure 2), we suppose that most likely the registered photo-effects are connected with biocatalyst photosensitive components participating in the EET. Photosensory proteins of the LOV (light, oxygen or voltage) and PYP (photoactive yellow protein) families have been recently determined in P. putida [37]. Though their particular functions in the cellular physiology remain unclear, it is suggested that these proteins may contribute to the observed light-induced current fluctuations. The gradual increase in the generated current (Figures 4 and 5a and Supplementary Figure S1) implies that at the applied polarization conditions P. putida 1046 formed electroactive biofilms and/or produced redox-active molecules mediating the EET. After 10 days of operation, the achieved current density with the modified electrodes was 2.5 to 10-times higher than the values achieved with $P$. putida entrapped in alginate redox-active polymer and carbon felt electrodes, independently of the improved redox conditions [26]. These findings suggest that the utilized metal oxides are appropriate anodic catalysts for the enhancement of the MFC electric characteristics. 


\section{Materials and Methods}

\subsection{Production and Characterization of Gr-MO Composites}

Three types of $\mathrm{Gr}-\mathrm{MO}$ composites $-\mathrm{Gr}-\mathrm{Fe}_{2} \mathrm{O}_{3}, \mathrm{Gr}-\mathrm{Fe}_{3} \mathrm{O}_{4}$, and $\mathrm{Gr}-\mathrm{Mn}_{3} \mathrm{O}_{4}$, as well as non-modified graphite with a geometric area of $4.2 \mathrm{~cm}^{2}$ were fabricated using a procedure resembling the method for producing synthetic graphite. The ingredients, namely $50 \mathrm{wt} . \%$ finely powdered spectroscopic graphite, 30 wt.\% carbon pitch (Koppers Inc., Pittsburg, PA, USA), and 20 wt.\% metal oxide $\left(\mathrm{Fe}_{2} \mathrm{O}_{3}, \mathrm{Fe}_{3} \mathrm{O}_{4}\right.$, or $\mathrm{Mn}_{3} \mathrm{O}_{4}$ ) as a catalyst precursor, were thoroughly mixed for $1 \mathrm{~h}$, pressed at $250 \mathrm{MPa}$ in a stainless steel form, sintered for $30 \mathrm{~min}$ at $150^{\circ} \mathrm{C}$, and then pyrolyzed at $800^{\circ} \mathrm{C}$ for $1 \mathrm{~h}$ under argon atmosphere. Titanium wires (1.6 $\mathrm{mm}$ thick) were screwed in the electrode samples and served as current collectors. The morphology of the developed materials was analyzed by scanning electron microscopy (SEM) using a JEOL 6300. The chemical composition and the crystal structure of the produced materials were examined by X-ray diffraction (XRD) using a Philips APD 15 X-ray diffractometer.

The corrosion behavior of the newly produced electrodes in a neutral electrolyte $(0.1 \mathrm{mM}$ PBS, $\mathrm{pH} 7.0$ ) was studied by linear voltammetry (LV) with a scan rate of $1 \mathrm{mV} / \mathrm{s}$. The investigations were carried out in a three-electrode cell with an electrolyte volume of $50 \mathrm{~cm}^{3}$. The tested electrodes were connected as working electrodes, and a plain titanium electrode was used as a counter electrode with an interelectrode distance of $2 \mathrm{~cm}$. All potentials were measured against an $\mathrm{Ag} / \mathrm{AgCl}(3.5 \mathrm{M} \mathrm{KCl})$ reference electrode. The obtained data were presented as Tafel plots. The electrochemical studies were performed by using PalmSens 3 equipped with a MUX8 multiplexer.

\subsection{Examination of Developed Electrodes in a Biotic Environment}

Before the electrochemical experiments, Pseudomonas putida 1046 was cultivated in a nutrient medium consisting of $10 \mathrm{~g} / \mathrm{L}$ meat extract, $10 \mathrm{~g} / \mathrm{L}$ peptone, $5 \mathrm{~g} / \mathrm{L} \mathrm{NaCl}$, and $1 \mathrm{~g} / \mathrm{L}$ glucose $[38,39]$ in an incubator at $30{ }^{\circ} \mathrm{C}$ and on an orbital shaker $(100 \mathrm{rpm})$. The bacteria were harvested by centrifugation at $5000 \mathrm{rpm}$ for $10 \mathrm{~min}$, and the pellet was washed twice with $0.1 \mathrm{mM}$ PBS and concentrated. Equal quantities of inoculum adjusted to an optical density of 0.770 at $600 \mathrm{~nm}$ wavelength were added in the three-electrode cells.

The electrochemical experiments were performed in identical three-electrode cells using the produced materials as working electrodes, titanium foil as counter electrodes, and $\mathrm{Ag} / \mathrm{AgCl}$ as reference electrodes. The working electrodes were poised simultaneously at applied potential $+0.2 \mathrm{~V}$ (vs. $\mathrm{Ag} / \mathrm{AgCl}$ ) by using PalmSens 3 equipped with MUX8 multiplexer for 10 days. Half of the electrolyte was replaced with fresh medium after 5 days of operation. During long-term chronoamperometric experiments, additional CV and EIS analyses were performed. CVs were carried out with a scan rate of $3 \mathrm{mV} / \mathrm{s}$ in a potential range between $-0.5 \mathrm{~V}$ and $+0.6 \mathrm{~V}$ (vs. $\mathrm{Ag} / \mathrm{AgCl}$ ). The EIS measurements were performed at applied $\mathrm{AC}$ with an amplitude of the signal of $10 \mathrm{mV}$ and $\mathrm{E}_{\mathrm{dc}}=+100 \mathrm{mV}(\mathrm{vs} . \mathrm{Ag} / \mathrm{AgCl})$ in the frequency range from $50 \mathrm{kHz}$ to $0.01 \mathrm{~Hz}$ by using a PalmSens 3 potentiostat with a frequency response analyzer (FRA) unit. The experiments were performed at $28{ }^{\circ} \mathrm{C}$ in a laminar box under sterile conditions.

\section{Conclusions}

Graphite-metal oxide composites (Gr-MO) containing Fe- and Mn-oxides were produced and tested as potential anodic catalysts for microbial fuel cells. The inclusion of the metal oxides in the graphite matrix was confirmed by SEM and XRD. As a result of the applied pyrolysis during preparation, the initial $\mathrm{Fe}_{2} \mathrm{O}_{3}$ and $\mathrm{Fe}_{3} \mathrm{O}_{4}$ were partially reduced, while the $\mathrm{Mn}_{3} \mathrm{O}_{4}$ was converted into $\mathrm{MnO}$. The newly fabricated $\mathrm{Gr}-\mathrm{MO}$ composites are mechanically stable and possess a more developed electroactive surface than the non-modified graphite produced at the same conditions. All modified electrodes generate higher anodic currents compared to the bare graphite in the presence of the bacterial strain Pseudomonas putida 1046 at applied external potential $+0.2 \mathrm{~V}$ (vs. Ag/AgCl). The highest current density, achieved with $\mathrm{Gr}-\mathrm{Mn}_{3} \mathrm{O}_{4}$, is associated with its most developed electroactive surface, 
the lowest charge transfer resistance and diffusion hindrances, as well as with the ability of P. putida spp. to produce biogenic $\mathrm{Mn}(\mathrm{IV})$ oxides and use them as a terminal electron acceptor for their catabolic processes. The better performance of $\mathrm{Gr}-\mathrm{Fe}_{2} \mathrm{O}_{3}$ compared to $\mathrm{Gr}-\mathrm{Fe}_{3} \mathrm{O}_{4}$ is assigned to the lower charge transfer and diffusion limitations of the current generation processes, determined by EIS. The observed light-dependent current oscillations are attributed to the bacterial contribution to the current generation and participation of photosensitive components like flavoproteins and outer membrane $c$-type cytochromes in the EET processes. Based on the obtained results it can be concluded that all modified graphite-metal oxide electrodes, especially $\mathrm{Gr}-\mathrm{Mn}_{3} \mathrm{O}_{4}$, can be applied as anodes in microbial fuel cells.

Supplementary Materials: The following are available online at http://www.mdpi.com/2073-4344/10/7/796/s1, Figure S1: Cyclic voltammograms of the investigated materials in non-inoculated cultivation medium, Table S1: Experimental XRD peaks compared to ICDD reference data, Table S2: Open circuit potentials before and after inoculation with bacteria.

Author Contributions: Conceptualization, M.M. and Y.H.; Methodology, I.B., M.M., and Y.H.; Investigation, E.C. and I.B.; Visualization, E.C. and I.B.; Validation, M.M. and Y.H.; Resources, M.M.; Project administration, Y.H.; Supervision, M.M. and Y.H.; Writing—original draft, E.C.; Writing—review and editing, M.M. and Y.H. All authors have read and agreed to the published version of the manuscript.

Funding: This research was funded by the Bulgarian National Science Fund, grant number KP-06-H29/8/2018, and partially by the Research Fund of South-West University "Neofit Rilski" - Blagoevgrad, Bulgaria, grant number RP-A5/20.

Acknowledgments: The authors are grateful for the financial support from the Bulgarian National Science Fund through grant KP-06-H29/8/2018 and South-West University "Neofit Rilski" through grant RP-A5/20. We are also thankful to Sasho Vassilev (IEES-BAS) for the XRD-analysis and to Ognian Dimitrov (IEES-BAS) for the SEM imaging.

Conflicts of Interest: The authors declare that there is no conflict of interest in submitting this manuscript and that the manuscript has been approved by all authors for publication.

\section{References}

1. Santoro, C.; Arbizzani, C.; Erable, B.; Ieropoulos, I. Microbial fuel cells: From fundamentals to applications. A review. J. Power Sources 2017, 356, 225-244. [CrossRef] [PubMed]

2. Baicha, Z.; Salar-García, M.J.; Ortiz-Martínez, V.M.; Hernández-Fernández, F.J.; de los Ríos, A.P.; Labjar, N.; Lotfi, E.; Elmahi, M. A critical review on microalgae as an alternative source for bioenergy production: A promising low cost substrate for microbial fuel cells. Fuel Process. Technol. 2016, 154, 104-116. [CrossRef]

3. Hindatu, Y.; Annuar, M.S.M.; Gumel, A.M. Mini-review: Anode modification for improved performance of microbial fuel cell. Renew. Sustain. Energy Rev. 2017, 73, 236-248. [CrossRef]

4. Zhou, M.; Chi, M.; Luo, J.; He, H.; Jin, T. An overview of electrode materials in microbial fuel cells. J. Power Sources 2011, 196, 4427-4435. [CrossRef]

5. Yuan, H.; Hou, Y.; Abu-Reesh, I.M.; Chen, J.; He, Z. Oxygen reduction reaction catalysts used in microbial fuel cells for energy-efficient wastewater treatment: A review. Mater. Horiz. 2016, 3, 382-401. [CrossRef]

6. Xia, C.; Zhang, D.; Pedrycz, W.; Zhu, Y.; Guo, Y. Models for Microbial Fuel Cells: A critical review. J. Power Sources 2018, 373, 119-131. [CrossRef]

7. Ilamathi, R.; Jayapriya, J. Microbial fuel cells for dye decolorization. Environ. Chem. Lett. 2018, 16, 239-250. [CrossRef]

8. Hubenova, Y.V.; Rashkov, R.S.; Buchvarov, V.D.; Arnaudova, M.H.; Babanova, S.M.; Mitov, M.Y. Improvement of Yeast-Biofuel Cell Output by Electrode Modifications. Ind. Eng. Chem. Res. 2011, 50, 557-564. [CrossRef]

9. Hubenova, Y.; Rashkov, R.; Buchvarov, V.; Babanova, S.; Mitov, M. Nanomodified NiFe- and NiFeP-carbon felt as anode electrocatalysts in yeast-biofuel cell. J. Mater. Sci. 2011, 46, 7074-7081. [CrossRef]

10. Manickam, S.S.; Karra, U.; Huang, L.; Bui, N.-N.; Li, B.; McCutcheon, J.R. Activated carbon nanofiber anodes for microbial fuel cells. Carbon 2013, 53, 19-28. [CrossRef]

11. Jayapriya, J.; Ramamurthy, V. Use of non-native phenazines to improve the performance of Pseudomonas aeruginosa MTCC 2474 catalysed fuel cells. Bioresour. Technol. 2012, 124, 23-28. [CrossRef] 
12. Shi, L.; Dong, H.; Reguera, G.; Beyenal, H.; Lu, A.; Liu, J.; Yu, H.-Q.; Fredrickson, J.K. Extracellular electron transfer mechanisms between microorganisms and minerals. Nat. Rev. Microbiol. 2016, 14, 651-662. [CrossRef]

13. Lovley, D.R.; Phillips, E.J.P. Novel Mode of Microbial Energy Metabolism: Organic Carbon Oxidation Coupled to Dissimilatory Reduction of Iron or Manganese. Appl. Environ. Microbiol. 1988, 54, 1472-1480. [CrossRef]

14. Aiyer, S.M.; Zahnow, R.; Mazerolle, L.A. Developmental transitions during adulthood and neighborliness: A multilevel cluster analysis. J. Commun. Psychol. 2020, 48, 237-257. [CrossRef] [PubMed]

15. Jung, B.; Schobert, H.H. Viscous sintering of coal ashes. 2. Sintering behavior at short residence times in a drop tube furnace. Energy Fuels 1992, 6, 59-68. [CrossRef]

16. Nel, M.V.; Strydom, C.A.; Schobert, H.H.; Beukes, J.P.; Bunt, J.R. Comparison of sintering and compressive strength tendencies of a model coal mineral mixture heat-treated in inert and oxidizing atmospheres. Fuel Process. Technol. 2011, 92, 1042-1051. [CrossRef]

17. Robinson, D.M.; Go, Y.B.; Mui, M.; Gardner, G.; Zhang, Z.; Mastrogiovanni, D.; Garfunkel, E.; Li, J.; Greenblatt, M.; Dismukes, G.C. Photochemical Water Oxidation by Crystalline Polymorphs of Manganese Oxides: Structural Requirements for Catalysis. J. Am. Chem. Soc. 2013, 135, 3494-3501. [CrossRef] [PubMed]

18. Talha, M.; Ma, Y.; Lin, Y.; Singh, A.; Liu, W.; Kong, X. Corrosion behaviour of austenitic stainless steels in phosphate buffer saline solution: Synergistic effects of protein concentration, time and nitrogen. New J. Chem. 2019, 43, 1943-1955. [CrossRef]

19. Paul, S.; Ghosh, A. Electrochemical characterization of $\mathrm{MnO}_{2}$ as electrocatalytic energy material for fuel cell electrode. J. Fuel Chem. Technol. 2015, 43, 344-351. [CrossRef]

20. Singh, N.; Geethika, M.; Eswarappa, S.M.; Mugesh, G. Manganese-Based Nanozymes: Multienzyme Redox Activity and Effect on the Nitric Oxide Produced by Endothelial Nitric Oxide Synthase. Chem. A Eur. J. 2018, 24, 8393-8403. [CrossRef]

21. Mohamed, H.O.; Obaid, M.; Poo, K.-M.; Ali Abdelkareem, M.; Talas, S.A.; Fadali, O.A.; Kim, H.Y.; Chae, K.-J. $\mathrm{Fe} / \mathrm{Fe}_{2} \mathrm{O}_{3}$ nanoparticles as anode catalyst for exclusive power generation and degradation of organic compounds using microbial fuel cell. Chem. Eng. J. 2018, 349, 800-807. [CrossRef]

22. Hubenova, Y.; Mitov, M. Mitochondrial origin of extracelullar transferred electrons in yeast-based biofuel cells. Bioelectrochemistry 2015, 106, 232-239. [CrossRef] [PubMed]

23. Sreelekshmy, B.R. Exploration of Electrochemcially Active Bacterial Strains for Microbial Fuel Cells: An Innovation in Bioelectricity Generation. J. Pure Appl. Microbiol. 2020, 14, 103-122. [CrossRef]

24. Gorby, Y.A.; Lovley, D.R. Electron Transport in the Dissimilatory Iron Reducer, GS-15. Appl. Environ. Microbiol. 1991, 57, 867-870. [CrossRef] [PubMed]

25. Wang, L.-S.; Wu, H.; Desai, S.R. Sequential Oxygen Atom Chemisorption on Surfaces of Small Iron Clusters. Phys. Rev. Lett. 1996, 76, 4853-4856. [CrossRef]

26. Hubenova, Y.; Hubenova, E.; Burdin, B.; Vladikova, D.; Mitov, M. Development of coupled redox active network in Ca-alginate polymer for immobilization of Pseudomonas putida 1046 on electrode surface. Electrochim. Acta 2019, 312, 432-440. [CrossRef]

27. Sultana, S.T.; Babauta, J.T.; Beyenal, H. Electrochemical biofilm control: A review. Biofouling 2015, 31, 745-758. [CrossRef]

28. Jiang, S.; Kim, D.-G.; Kim, J.-H.; Ko, S.-O. Characterization of the Biogenic Manganese Oxides Produced by Pseudomonas putida strain MnB1. Environ. Eng. Res. 2010, 15, 183-190. [CrossRef]

29. Banh, A.; Chavez, V.; Doi, J.; Nguyen, A.; Hernandez, S.; Ha, V.; Jimenez, P.; Espinoza, F.; Johnson, H.A. Manganese (Mn) Oxidation Increases Intracellular Mn in Pseudomonas putida GB-1. PLoS ONE 2013, 8, e77835. [CrossRef]

30. Thangasamy, P.; Sathish, M. Dwindling the re-stacking by simultaneous exfoliation of boron nitride and decoration of $\alpha-\mathrm{Fe}_{2} \mathrm{O}_{3}$ nanoparticles using a solvothermal route. New J. Chem. 2018, 42, 5090-5095. [CrossRef]

31. Li, P.; Yan, X.; Ji, J.; Wu, Y.; Hu, J.; Wang, Y.; Jiang, H.; Zhang, W. Monocrystalline hematite nanostructures: Three-dimensionally oriented aggregation synthesis and their comparative visible-light photocatalytic activities. CrystEngComm 2017, 19, 1926-1932. [CrossRef]

32. Mani, D.; Mathivanan, D.; Chang, H.; Sakthivel, K.; Elangovan, E.; Sivakumar, T.; Arivanandhan, M.; Jayavel, R. A facile synthesis of novel $\varepsilon-\mathrm{Fe}_{2} \mathrm{O}_{3}$ grafted $2 \mathrm{D}$ h-BN nanostructures for enhanced visible active photocatalytic applications. New J. Chem. 2020. [CrossRef] 
33. Liu, H.; Tong, M.; Zhu, K.; Liu, H.; Chen, R. Preparation and photo-fenton degradation activity of $\alpha-\mathrm{Fe}_{2} \mathrm{O}_{3}$ nanorings obtained by adding $\mathrm{H}_{2} \mathrm{PO}_{4}{ }^{-}, \mathrm{SO}_{4}{ }^{2-}$, and citric acid. Chem. Eng. J. 2020, 382, 123010. [CrossRef]

34. Zhang, L.; Lian, J.; Wu, L.; Duan, Z.; Jiang, J.; Zhao, L. Synthesis of a Thin-Layer $\mathrm{MnO}_{2}$ Nanosheet-Coated $\mathrm{Fe}_{3} \mathrm{O}_{4}$ Nanocomposite as a Magnetically Separable Photocatalyst. Langmuir 2014, 30, 7006-7013. [CrossRef] [PubMed]

35. Nevárez-Martínez, M.C.; Kobylański, M.P.; Mazierski, P.; Wółkiewicz, J.; Trykowski, G.; Malankowska, A.; Kozak, M.; Espinoza-Montero, P.J.; Zaleska-Medynska, A. Self-Organized $\mathrm{TiO}_{2}-\mathrm{MnO}_{2}$ Nanotube Arrays for Efficient Photocatalytic Degradation of Toluene. Molecules 2017, 22. [CrossRef]

36. Cheng, S.-H.; Weng, T.-M.; Lu, M.-L.; Tan, W.-C.; Chen, J.-Y.; Chen, Y.-F. All Carbon-Based Photodetectors: An eminent integration of graphite quantum dots and two dimensional graphene. Sci. Rep. 2013, 3, 2694. [CrossRef]

37. van der Horst, M.A.; Key, J.; Hellingwerf, K.J. Photosensing in chemotrophic, non-phototrophic bacteria: Let there be light sensing too. Trends Microbiol. 2007, 15, 554-562. [CrossRef] [PubMed]

38. Park, I.H.; Christy, M.; Kim, P.; Nahm, K.S. Enhanced electrical contact of microbes using $\mathrm{Fe}_{3} \mathrm{O}_{4} / \mathrm{CNT}$ nanocomposite anode in mediator-less microbial fuel cell. Biosens. Bioelectron. 2014, 58, 75-80. [CrossRef]

39. Carmona-Martínez, A.A.; Harnisch, F.; Kuhlicke, U.; Neu, T.R.; Schröder, U. Electron transfer and biofilm formation of Shewanella putrefaciens as function of anode potential. Bioelectrochemistry 2013, 93, 23-29. [CrossRef]

(C) 2020 by the authors. Licensee MDPI, Basel, Switzerland. This article is an open access article distributed under the terms and conditions of the Creative Commons Attribution (CC BY) license (http://creativecommons.org/licenses/by/4.0/). 